\title{
THE RELATIONSHIP BETWEEN STUDENTS' SELF-EFFICACY IN LEARNING ENGLISH AND THEIR ENGLISH LEARNING ACHIEVEMENT AT THE TENTH GRADE OF SMAN 04 SOUTH TAMBUN IN 2019/2020 ACADEMIC YEAR
}

\author{
Fernindy Fitra Gumanti; Nita Kaniadewi \\ University of Muhammadiyah Prof. Dr. HAMKA \\ fernindyf@gmail.com; nitakaniadewi@uhamka.ac.id
}

\begin{abstract}
The objective of this study was to find out the relation between students' self-efficacy belief in learning English and their English learning achievement of the tenth grade students of SMAN 4 South Tambun in 2019/2020 academic year. This study used correlational study between two variables which was included in quantitative research. In this study, the writer took one class of tenth grade students which consist of 36 students as the sample. The writer found the correlation coefficient (r) result between students' self-efficacy in learning English and their English learning achievement which was 0,628. Afterward, the writer compared $r$ result to the interpretation of correlation table and showed there was positive correlation. Thus, it proves that self-efficacy belief encourages and helps students to improve their skills and self-confidence, and finally achieve better learning outcomes.
\end{abstract}

Keywords: Self-Efficacy, Learning, Learning Achievement, English Learning Achievement.

\section{INTRODUCTION}

English is learned by Indonesian students gradually from the first grade of junior high school up to university level however the students' English mastery is still quite limited. It is because English is only used as a foreign language and the students do not use it in their daily life as a communication tool. It is proven by their low English scores at school. There are few elements of social cognitive theory influence students' learning, one of them is self-efficacy (Dinther, Dochy, \& Segers, 2011). Self-efficacy concept is linked to everyone's belief in evaluating their capabilities to perform given tasks successfully (Goulao, 2014). It means student's learning outcome is influenced by self-efficacy that all students have.

Moreover Chao, Mclnerney, and Bai (2018) state that self-efficacy affects students' learning achievements. Bandura(1997, 2010) also stated that self-efficacy is a belief that influences things and gives an effect or change in people's lives. This belief changes people's motivation, performance, achievement, and emotion. Students who have strong self-efficacy beliefs can organize their learning strategy and to maintain the social pressures and temptations to engage in bad behaviors that can undermine their academic achievements and proficiency (Carroll et al., 
2009). Bandura (1997) perceives that those who have a strong self-efficacy, the higher the set of goals for themselves, and the firmer their commitment to them. In other words, students who have strong self-efficacy beliefs are able to motivate and develop their abilities in organizing and executing tasks completely and which in turn will help them in maintaining good academic achievement.

According to Bandura (1997), there are 4 factors that influence self-efficacy. Those are; practicing and earlier experiences, vicarious experiences, verbal persuasion, physiological and emotional states. An experience by own self is one of an important sources of self-efficacy. Successes create a strong belief in one's individual efficacy (Bandura, 1997). Which means, the students who have successful experiences in doing their tasks in the past will be more confident in facing the same difficult tasks in the future. Moreover, Vicarious experiences can also influence individuals' self-efficacy by someone whom they assume having the same ability, competence, and intelligence (Bandura, 1997). By comparing others' successes in doing the same task will make people think that they can do it too. Self-efficacy can also be developed by verbal persuasion. Giving advices, instructions, and suggestions can help improving personal's self-efficacy to be successful in doing something. Lastly, Physiological and emotional states influence an individual's self-efficacy itself. People expect to be more successful when they are not in a stressful situation than when they are. Stress and depression have a negative impact or undermine one's self-efficacy belief. What people think or believe about their illness will influences their self-efficacy belief to deal with their illness (Zulkosky, 2009).

Previous studies have discussed about the relation between students' self-efficacy and their English learning achievement. Chao, Mclnerney, and Bai (2018) examined the relation between self-efficacy, self-concept, and their relevancy to academic achievements in English and Chinese learning in Hong Kong. The sample of this study were 1092 students (464 females, 620 males and 8 unreported) with a mean age of 14.63 years old were taken from four secondary schools in Hong Kong. All the participants were taken from two secondary schools which are 402 students using Chinese, and the other two schools which are 690 students using English. This study adopted a questionnaire survey. The findings stated that self-efficacy and self-concept in the Chinese language were significant predictors for Chinese language achievements, whereas self-efficacy and self-concept in English predicted students' English and Chinese learning achievements.

Moreover, Carroll, A., Gordon, L., Bower, J., Houghton, S., Wood, R., Unsworth, K., \& Hattie, J. (2009) examined the relations among self-efficacy, delinquency, and academic aspirations on the Australian students' academic achievements. The participants were 935 students (aged 11 -18 years old) were randomly taken from ten schools in two Australian cities. This study adopted three scales for the measurement, which are The Perceived Self Efficacy Scale for Children, Adapted Self-Report Delinquency Scale (Revised), and The Academic Aspirations Scale for Children. The findings stated that through delinquency and a direct desirable impact, academic and self-regulatory efficiency had an indirect negative impact on academic achievement. Academic and social self-reliance respectively had positive and negative relationships with academic aspiration and academic achievement. 
In Addition, Lee, Myung and Bong (2014) also examined as an affective motivational variable, individual interest could predict academic self-regulation and achievement beyond what academic self-efficacy predicted in four subject areas (Korean, Math, English and Science). The participants were five hundred of Korean middle school students (132 students from the 7th grade, 239 students from the 8th grade, and 129 students from the 9th grade) from two middle schools in two suburban cities near Seoul, Korea, participated in two different surveys. This study adopted a quantitative method. The findings indicated that self-efficacy predicted achievements through grade targets, both directly and indirectly.

Based on those explanations above, this study aims to answer the research questions that "Is there any significant relationship between students' self-efficacy in learning English and their English learning achievement at the tenth grade of SMAN 4 South Tambun of 2019/2020 academic year?" and If yes, "how well is the level of students' self-efficacy in learning English?". Although the study related students' self-efficacy on their English learning achievement abound in literature (Carroll et al., 2009; Chao et al., 2018; Goulao, 2014) in Indonesia a similar study especially in secondary school is rarely unexplored. Thus, it is important to examine the relationship between students' self-efficacy in learning English and their English learning achievement, specifically in Indonesian secondary school (SMAN 04 South Tambun). This study will provide information to English teachers on how students' English learning achievements are related to their self-efficacy. By providing this information, English language teachers' should be more conscious of the significance of self-efficacy concepts in students' language learning (Chao et al., 2018)

\section{METHOD}

In this study, the respondents consisted 36 students chosen from one class among all the tenth grade of SMAN 4 South Tambun students. They were chosen using the random sampling technique. The research design was correlational study. The instruments used in recent study were questionnaire and documentation. the questionnaire was used to gain the students' self-efficacy data in learning English. Five out of fifteen item questionnaires were adapted from the scale of the Motivated Strategies for Learning Questionnaire (MSLQ), specifically in self efficacy for learning and performance by Pintrich (1991). Seven items of the questionnaires were made by Peng (2001) which was adapted in Pan and Wu (2013). The other items of the questionnaires were adapted from Bandura and Schunk $(1997,2010 ; 1984)$. While, The documentation was used to gain the data of students' score in English lesson of the Final Exam in the 2019/2020 academic year which were prepared by the English teacher in SMAN 4 South Tambun. The writer copied the English scores from 36 students and compared with the result of the questionnaires that had been distributed. The Croncbach Alpha for the self-efficacy instrument was 0,802. This recent study used Pearson's Product Moment Correlation Coefficient and the result was compared to the the interpretation of product moment scale by Ananda and Fadhli (2018) that described the relation between two variables. 


\section{FINDINGS AND DISCUSSION}

The first finding shown to find out the level of students' self-efficacy in learning English. The findings found from 36 students, there were three categories of self-efficacy score which was formed by making the table of distribution of frequency of students' self-efficacy (Table 1). They were low self-efficacy (45-52), medium self-efficacy (53-62), and high self-efficacy (63-72). Based on those three categories, it can be concluded that the level of students' self-efficacy score was medium level with 26 students $(72,28 \%)$ out of 36 students. The table and charts will be shown below.

Table 1. Table of Distribution of Frequency of Self-Efficacy

\begin{tabular}{|c|c|c|c|}
\hline Number & Interval & $\begin{array}{c}\text { Frequency } \\
\text { (f) }\end{array}$ & Percentage \\
\hline 1 & $43-47$ & 2 & $5,56 \%$ \\
\hline 2 & $48-52$ & 3 & $8,30 \%$ \\
\hline 3 & $53-57$ & 10 & $27,78 \%$ \\
\hline 4 & $58-62$ & 16 & $44,50 \%$ \\
\hline 5 & $63-67$ & 2 & $5,56 \%$ \\
\hline 6 & $68-72$ & 3 & $8,30 \%$ \\
\hline \multicolumn{4}{|c}{$\sum f=36$} \\
\hline
\end{tabular}

Figure 1: Pie Chart of Distribution of Frequency of Students' Self-Efficacy

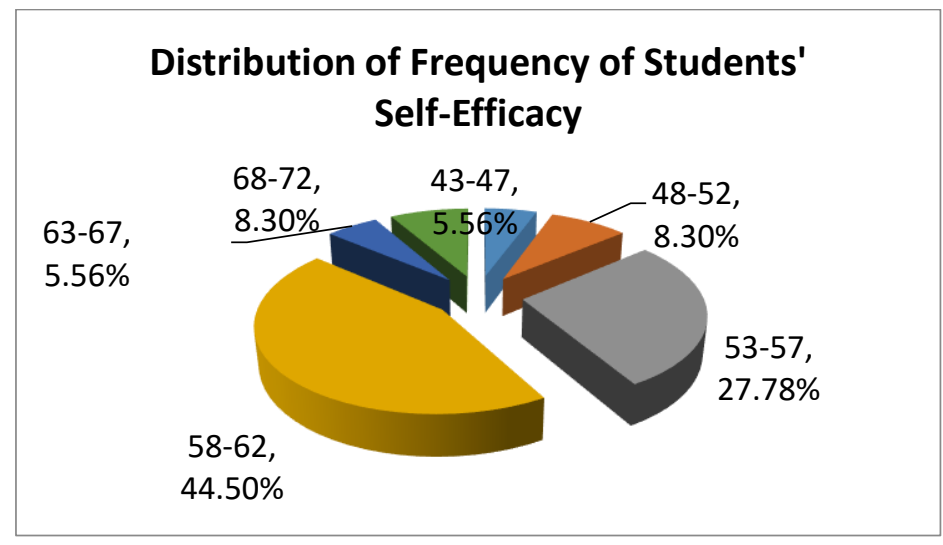

Figure 2: Bar Chart of Distribution of Frequency of Students' Self-Efficacy 


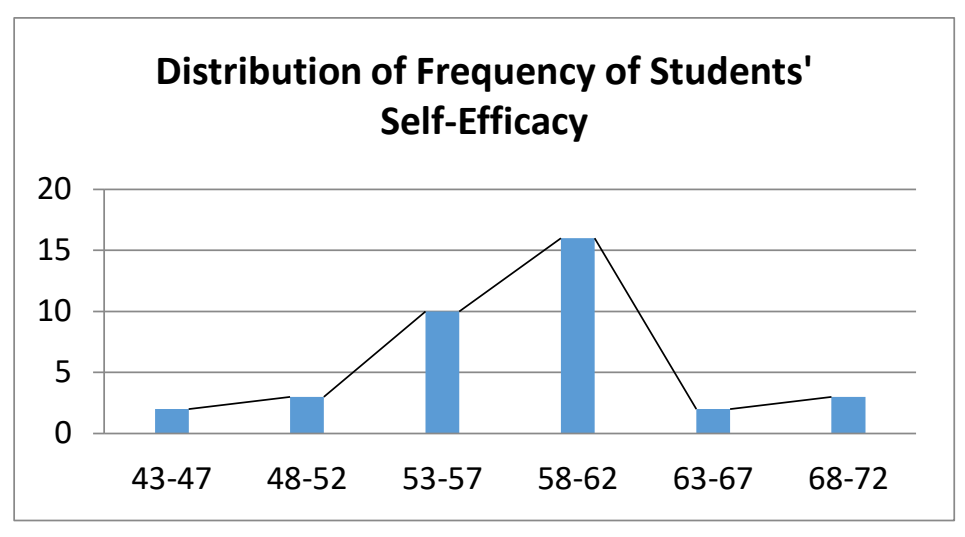

Shortly, 26 students out of 36 students had medium level of self-efficacy. Or it could be said that some of the students had low self-efficacy and some had high self-efficacy. This could be due to their earlier experiences who have never used English in daily life. Successes create a strong belief in one's individual efficacy (Bandura, 1997). Which means in this case, having experiences in using English will increase confidence in dealing similar situation. Otherwhise, this makes students unmotivated because they have not found the function of using English in their real life.

Furthermore, in order to explore the relation between students' self-efficacy and their English achievement, it was utilized Pearson product moment correlation coefficients. The result was compared to the interpretation of product moment scale by Ananda and Fadhli (2018) that described the relation between two variables.

Table 2 : Correlation between Students' Self-Efficacy and Their English Learning Achievement Correlations

\begin{tabular}{|c|c|c|c|}
\hline & & Self-Efficacy & $\begin{array}{c}\text { English } \\
\text { Achievement }\end{array}$ \\
\hline \multirow[t]{3}{*}{ Self-Efficacy } & $\begin{array}{c}\text { Pearson } \\
\text { Correlation }\end{array}$ & 1 &, $628^{* \star}$ \\
\hline & Sig. (2-tailed) & &, 000 \\
\hline & $\mathrm{N}$ & 36 & 36 \\
\hline \multirow[t]{3}{*}{$\begin{array}{c}\text { English } \\
\text { Achievement }\end{array}$} & $\begin{array}{l}\text { Pearson } \\
\text { Correlation }\end{array}$ &, $628^{* *}$ & 1 \\
\hline & Sig. (2-tailed) &, 000 & \\
\hline & $\mathrm{N}$ & 36 & 36 \\
\hline
\end{tabular}

Table 3: The Interpretation of Correlation (Ananda \& Fadhli, 2018)

\begin{tabular}{|c|c|}
\hline $\mathbf{R}$ & \multicolumn{1}{|c|}{ Interpretation } \\
\hline $0,00-0,20$ & There is a very weak or very low correlation \\
\hline $0,20-0,40$ & There is a weak or low correlation \\
\hline
\end{tabular}




\begin{tabular}{|l|l|}
\hline $0,40-0,70$ & There is an enough correlation \\
\hline $0,70-0,90$ & There is a strong or high correlation \\
\hline $0,90-1,00$ & There is a very strong or very high correlation \\
\hline
\end{tabular}

From the calculation of SPSS above, it showed the correlation coefficient $\left(r_{x y}\right)$ was 0,628 which indicates the positive correlation between self-efficacy and English learning achievement. The writer compared the result by looking at the correlation interpretation table in the previous chapter to see how strong the correlation is. From the table, it stated that there was correlation $(0,40-0,70)$ between self-efficacy (as $\mathrm{X}$ variable) and English learning achievement (as $\mathrm{Y}$ variable).

These two variables had positive correlation in that the students of SMAN 4 South Tambun might had high level of self-efficacy belief in organizing their persistence and effort during English class. As explained above, self-efficacy is needed to encourage students' cognitive, motivational, affective, and selection processes in their brain which are lead to the goals of learning and achieve the best score. Thus, during the English learning process took place, students' self-efficacy at that time influenced students' performance, emotion, motivation, and achievement in English lesson. Their belief in themselves was the element key here. Shortly, the higher the students' self-efficacy, the higher the achievement scores they will get. It showed from the students' score of both the variables.

\section{CONCLUSIONS}

Based on the research findings and discussions avoe, there was positive significant relationship between students' self-efficacy in learning English and their English learning achievements at the tenth grade students of SMAN 4 South Tambun. Therefore, it also can be concluded that the higher the level of students' self-efficacy in learning English, the higher their English achievement scores. Furthermore, the writer still found some students who had low scores both in self-efficacy and English achievement. Moreover, from the relative frequency distribution of self-efficacy in chapter 4 the writer found the level of students' self-efficacy was in medium level with 26 students $(72,28 \%)$ out of 36 students. All in all, according to the research findings, the students' selfefficacy influences their English learning achievement.

\section{REFERENCES}

Ananda, R., \& Fadhli, M. (2018). Statistik Pendidikan: Teori dan Praktik Dalam Pendidikan. (S. Saleh, Ed.). Medan: CV. Widya Puspita.

Bandura, A. (1997). Self-efficacy: The exercise of control. New York: MacMillan.

Bandura, A. (2010). Self-Efficacy. The Corsini Encyclopedia of Psychology. 
https://doi.org/10.1002/9780470479216.corpsy0836.

Carroll, A., Gordon, L., Bower, J., Houghton, S., Wood, R., Unsworth, K., \& Hattie, J. (2009). Self-efficacy and academic achievement in Australian high school students: The mediating effects of academic aspirations and delinquency. Journal of Adolescence, 32, 797-817.

Chao, C. N. G., McInerney, D. M., \& Bai, B. (2018). Self-efficacy and self-concept as predictors of language learning achievements in an asian bilingual context. The Asia-Pacific Education Researcher, 28(2), 139-147. https://doi.org/doi:10.1007/s40299-018-0420-3.

Dinther, M. Van, Dochy, F., \& Segers, M. (2011). Factors affecting students' self-efficacy in higher education. Educational Research Review, 6(2), 95-108.

Goulao, M. de F. (2014). The Relationship between Self-Efficacy and Academic Achievement in Adults' Learners. Athens Journal of Education, 1(3), 237-246.

Lee, W., Lee, M.-J., \& Bong, M. (2014). Testing interest and self-efficacy as predictors of academic self-regulation and achievement. Contemporary Educational Psychology, 39, 8699.

Pan, C.-P., \& Wu, H.-Y. (2013). The Cooperative Learning Effects on English Reading Comprehension and Learning Motivation of EFL Freshmen. English Language Teaching, 6(5), 13-27.

Peng, I. N. (2001). efl motivation and strategy use among taiwanese senior high school learners. Unpublished MA Dissertation, National Taiwan Normal University.

Pintrich, P. R. (1991). A manual for the use of the Motivated Strategies for Learning Questionnaire (MSLQ). Michigan: University of Michigan.

Schunk, D. (1984). Enhancing self-efficacy and achievement through rewards and goals: motivational and informational effects. The Journal of Educational Research, 78(1), 29-34.

Zulkosky, K. (2009). Self-Efficacy: A Concept Analysis. Nursing Forum, 44(2), 93-102. 